\title{
Antibacterial Activities of Metabolites Produced by Erwinia spp. against Various Phytopathogenic Bacteria
}

\author{
Masanori NishIOKA**, Naruto FURUYA*, Nobuhiko NAKASHIMA*** \\ and Nobuaki MATSUYAMA*
}

Key words : Erwinia spp., antibacterial activity.

The production of antibiotics by Actinomycetes species ${ }^{6,17,19)}$ and the antagonistic activity of bacteria against plant pathogens ${ }^{4,5,10,18)}$ have both been well documented. Previously, we also reported the production of anti-bacterial and -fungal substances by phytopathogenic pseudomonads and xanthomonads $s^{2,3,11-16,20)}$. In addition, the authors recently found Erwinia spp. which were active against various species of phytopathogenic bacteria.

Eighty strains of Erwinia spp. isolated in Japan and Thailand were screened for production of substances effective against seven species plant pathogenic bacteria. All strains were maintained on PSA medium (potato semi-synthetic agar medium ; $5 \mathrm{~g}$ peptone, $15 \mathrm{~g}$ sucrose, 2 $\mathrm{g} \mathrm{Na}_{2} \mathrm{HPO}_{4} \cdot 12 \mathrm{H}_{2} \mathrm{O}, 0.5 \mathrm{~g} \mathrm{Ca}\left(\mathrm{NO}_{3}\right)_{2} \cdot 4 \mathrm{H}_{2} \mathrm{O}$ and $15 \mathrm{~g}$ agar/ 1 of potato $(300 \mathrm{~g})$ decoction, $\mathrm{pH} 7.0)$.

The production of antibacterial substances was detected by the plate-chloroform method ${ }^{2}$. Each strain of Erwinia spp. was spotted on the surface of YPDA medium (yeast peptone dextrose agar medium; $0.6 \mathrm{~g}$ peptone, $3 \mathrm{~g}$ glucose, $3 \mathrm{~g}$ yeast extract and $15 \mathrm{~g}$ agar $/ \mathrm{l}$, $\mathrm{pH} 7.2$ ) in a petri dish, incubated at $30^{\circ} \mathrm{C}$ for $48 \mathrm{hr}$ and exposed to chloroform vapor for $2 \mathrm{hr}$. The plate was overlaid with $5 \mathrm{ml}$ of melted YPDA medium containing $0.5 \%(\mathrm{w} / \mathrm{v})$ agar and $c a .10^{7} \mathrm{cfu} / \mathrm{ml}$ of the indicator bacterium. Antibacterial activity was estimated by measuring the diameter of the inhibition zone around the colony of the producer after incubation at $30^{\circ} \mathrm{C}$ for 24-48 hr.

As shown in Table 1, thirty eight strains of Erwinia spp. which included $E$. carotovora subsp. carotovora, $E$. chrysanthemi pv. chrysanthemi, E. chrysanthemi pv. zeae, $E$. chrysanthemi (pathovar unidentified) showed antibacterial activity against at least one phytopathogenic bacterium used as an indicator. The activity spectra differed greatly among Thai and Japanese strains of Erwinia spp. Several strains of $E$. carotovora subsp. carotovora obtained in Thailand strongly inhibited the growth of Clavibacter michiganensis subsp. michiganen- sis, Xanthomonas oryzae pv. oryzae and Pseudomonas solanacearum. None of the Thai and Japanese strains of Erwinia spp. showed any antibacterial activity against $P$. cepacia or $X$. campestris pv. citri.

The production of anti- $P$. solanacearum substance(s) by Thai strains of $E$. carotovora subsp. carotovora strains was tested by the plate-chloroform method on Kado's 523, MKA, KBA, MMA, PSA and PA in addition to YPDA. The ingredients of the media stated above are as follows: Kado's 523 medium ( $10 \mathrm{~g}$ sucrose, $8 \mathrm{~g}$ casein enzymatic hydrolysate, $4 \mathrm{~g}$ yeast extract, $2 \mathrm{~g} \mathrm{~K}_{2} \mathrm{HPO}_{4}$, $0.3 \mathrm{~g} \mathrm{MgSO}_{4} \cdot 7 \mathrm{H}_{2} \mathrm{O}$ and $15 \mathrm{~g}$ agar $\left./ 1\right)^{8)}$; modified Kelman's agar (MKA) medium (10 g peptone, $5 \mathrm{~g}$ glucose, $1 \mathrm{~g}$ casein enzymatic hydrolysate and $15 \mathrm{~g}$ agar/l) $)^{9)}$; King's $\mathrm{B}$ agar (KBA) medium (20 $\mathrm{g}$ proteose peptone No. 3 (Difco), $1.5 \mathrm{~g} \mathrm{~K}_{2} \mathrm{HPO}_{4}, 1.5 \mathrm{~g} \mathrm{MgSO}_{4} \cdot 7 \mathrm{H}_{2} \mathrm{O}, 10 \mathrm{ml}$ glycerol and $15 \mathrm{~g}$ agar/l); Minimal agar medium (MMA) $(0.1 \mathrm{~g}$ $\mathrm{MgSO}_{4} \cdot 7 \mathrm{H}_{2} \mathrm{O}, 1 \mathrm{~g}\left(\mathrm{NH}_{4}\right)_{2} \mathrm{SO}_{4}, 3 \mathrm{~g} \mathrm{~K}_{2} \mathrm{HPO}_{4}, 3 \mathrm{~g} \mathrm{KH}_{2} \mathrm{PO}_{4}$, $5 \mathrm{~g}$ glucose and $15 \mathrm{~g}$ agar/1) and PA (15 $\mathrm{g}$ agar per liter of potato $(300 \mathrm{~g})$ decoction, $\mathrm{pH} 7.0)$.

The production of anti- $P$. solanacearum substance(s) by Thai strains of $E$. carotovora subsp. carotovora varied with the strains and media used. As can be seen in Table 2, all Thai strains strongly inhibited $P$. solanacearum on PSA and PA medium, whereas none did so on MMA medium. The majority of Thai strains of $E$. carotovora subsp. carotovora were active against $P$. solanacearum but all Japanese strains of the subspecies were negative. To elucidate the reason for the difference in antibacterial substance(s) production between Thai and Japanese strains of $E$. carotovora subsp. carotovora, data for other strains from different geographic regions must be accumulated. The activity of Japanese strains of Erwinia spp. against Thai indicator bacteria will be the subject for future study.

The production of anti- $P$. solanacearum substance(s) by Thai strains of $E$. carotovora subsp. carotovora in liquid media was also tested. In Kado's 523, MK, KB, MM, PS, $\mathrm{P}$ and YPD liquid media, the bacteria were

\footnotetext{
* Faculty of Agriculture, Kyushu University, Fukuoka 812-81, Japan九州大学農学部

** Present address: Nissan Chemical Industries, Ltd. Shiraoka Research Station of Biological Science, 1470 Shiraoka, Minamisaitama-gun, Saitama 349-02, Japan 現在：日産化学工業株式会社

*** Present address : National Institute of Sericultural and Entomological Science, Tsukuba 305, Japan 現在：虫系・昆 虫農業技術研究所
} 
Table 1. Antibacterial activity of Enwinia spp. from Thailand and Japan against phytopathogenic indicator bacteria on yeast potato dextrose agar

\begin{tabular}{|c|c|c|c|c|c|c|c|c|c|}
\hline \multirow{3}{*}{ Producer } & \multicolumn{7}{|c|}{ Width of inhibition zone $e^{a)}$} & \multirow{2}{*}{\multicolumn{2}{|c|}{ Source }} \\
\hline & \multicolumn{7}{|c|}{ Indicator $^{\mathrm{b})}$} & & \\
\hline & A.t. & C.m. & P.c. & P.sol. & P.syr. & X.c. & X.o. & Geographic & Donor ${ }^{c}$ \\
\hline \multirow{3}{*}{\multicolumn{10}{|c|}{$\begin{array}{l}\text { Erwinia } \\
\text { carotovora } \\
\text { subsp. carotovora }\end{array}$}} \\
\hline & & & & & & & & & \\
\hline & & & & & & & & & \\
\hline $014-2$ & ++ & - & - & - & - & - & - & Thailand & LSPPM \\
\hline $131-1$ & - & + & - & + & + & - & - & $n$ & $n$ \\
\hline $131 \cdot 2$ & - & - & - & - & - & - & + & $n$ & $"$ \\
\hline $168-7$ & - & + & - & + & - & - & - & $n$ & $n$ \\
\hline $435-2$ & - & +++ & - & +++ & - & - & ++ & $\prime \prime$ & $n$ \\
\hline $435-6$ & - & +++ & - & +++ & - & - & +++ & $" 1$ & $n$ \\
\hline $463-1$ & - & ++ & - & - & - & - & - & $n$ & $n$ \\
\hline $473-1$ & ++ & - & - & ++ & - & - & - & " & $n$ \\
\hline $486-5$ & - & + & - & + & - & - & - & $n$ & $n$ \\
\hline $489-5$ & - & +++ & - & +++ & - & - & +++ & $n$ & $n$ \\
\hline $493-1$ & - & +++ & - & +++ & - & - & +++ & $n$ & $n$ \\
\hline $493-5$ & - & - & - & + & - & - & - & 11 & $n$ \\
\hline N7101 & - & + & - & - & - & - & - & Japan & NIAES \\
\hline N7128 & - & + & - & - & - & - & - & "I & $n$ \\
\hline N7129 & - & + & - & - & - & - & - & $n$ & " \\
\hline N7157 & - & + & - & - & - & - & - & $n$ & $n$ \\
\hline Ku7514 & - & + & - & - & - & - & - & $\eta$ & KU \\
\hline Sr79-33-3 & - & - & - & - & - & - & + & $n$ & HPAES \\
\hline S8488 & - & - & - & - & - & - & + & $n$ & $n$ \\
\hline S84812 & - & - & - & - & - & - & + & $n$ & $n$ \\
\hline $645 \mathrm{ar}$ & - & - & - & - & - & - & ++ & $n$ & IU \\
\hline $\operatorname{ar} 13$ & - & - & - & - & + & - & - & $n$ & $n$ \\
\hline $\mathrm{K} 1$ & - & + & - & - & - & - & - & 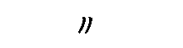 & $\mathrm{KU}$ \\
\hline $\mathrm{B} 1$ & - & + & - & - & - & - & - & $n$ & $n$ \\
\hline $1 \mathrm{~B}$ & - & + & - & - & - & - & - & $n$ & YU \\
\hline $\mathrm{T} 14$ & - & - & - & - & - & - & + & $n$ & $\mathrm{IU}$ \\
\hline T21-1 & - & - & - & - & - & - & ++ & $n$ & $n$ \\
\hline 2 & - & - & - & - & - & - & ++ & $n$ & $n$ \\
\hline \multicolumn{10}{|c|}{$\begin{array}{l}E \text {. chrysanthemi } \\
\text { pv. chrysanthemi }\end{array}$} \\
\hline $\mathrm{E} 8301$ & - & + & - & + & - & - & - & $n$ & SZU \\
\hline Ku7601 & - & + & - & + & - & - & ++ & $n$ & $\mathrm{KU}$ \\
\hline \multicolumn{10}{|l|}{ pv. zeae } \\
\hline $\mathrm{R} 7$ & - & + & - & - & - & - & + & " & SZU \\
\hline $\mathrm{R} 8$ & - & + & - & - & - & - & + & $"$ & $n$ \\
\hline ALE829p & - & + & - & + & - & - & - & 11 & $n$ \\
\hline $511-3$ & - & ++ & - & - & - & - & - & Thailand & LSPPM \\
\hline \multicolumn{10}{|l|}{$\begin{array}{l}\text { (pathovar } \\
\text { unidentified) }\end{array}$} \\
\hline $342-15$ & - & + & - & + & - & - & ++ & " & $"$ \\
\hline $342-16 \mathrm{~S}$ & - & + & - & + & - & - & + & 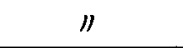 & $\prime \prime$ \\
\hline Ech33 & - & + & - & - & - & - & + & Japan & $\mathrm{KU}$ \\
\hline Ech44 & - & + & - & - & - & - & + & " & $n$ \\
\hline
\end{tabular}

a) Activity index (diameter of inhibition zone): - , not detected; + , less than $5 \mathrm{~mm} ;++, 5 \sim 10 \mathrm{~mm} ;+++$, greater than $10 \mathrm{~mm}$.

b) Abbreviations for indicator bacteria : A.t., Agrobacterium tumefaciens Ku7411; C.m., Clavibacter michiganensis subsp. michiganensis N6203 ; P.c., Pseudomonas cepacia 356-2 ; P.sol., P.solanacearum C319 ; P. syr., P. syringae pv. syringae 1 ; X. c., Xanthomonas campestris pv. citri Ku7517 ; X.o., X. oryzae pv. oryzae Q7463.

c) Abbreviations for culture collections: LSPPM, Laboratory of Seed and Post-Harvest Disease, Plant Pathology and Microbiology Division, Department of Agriculture, Thailand; NIAES, National Institute of Argo-Environmental Sciences ; KU, Kyushu University ; HPAES, Hokkaido Prefectural Agricultural Experiment Station ; IU, Iwate University : YU, Yamagata University; SZU, Shizuoka University. 


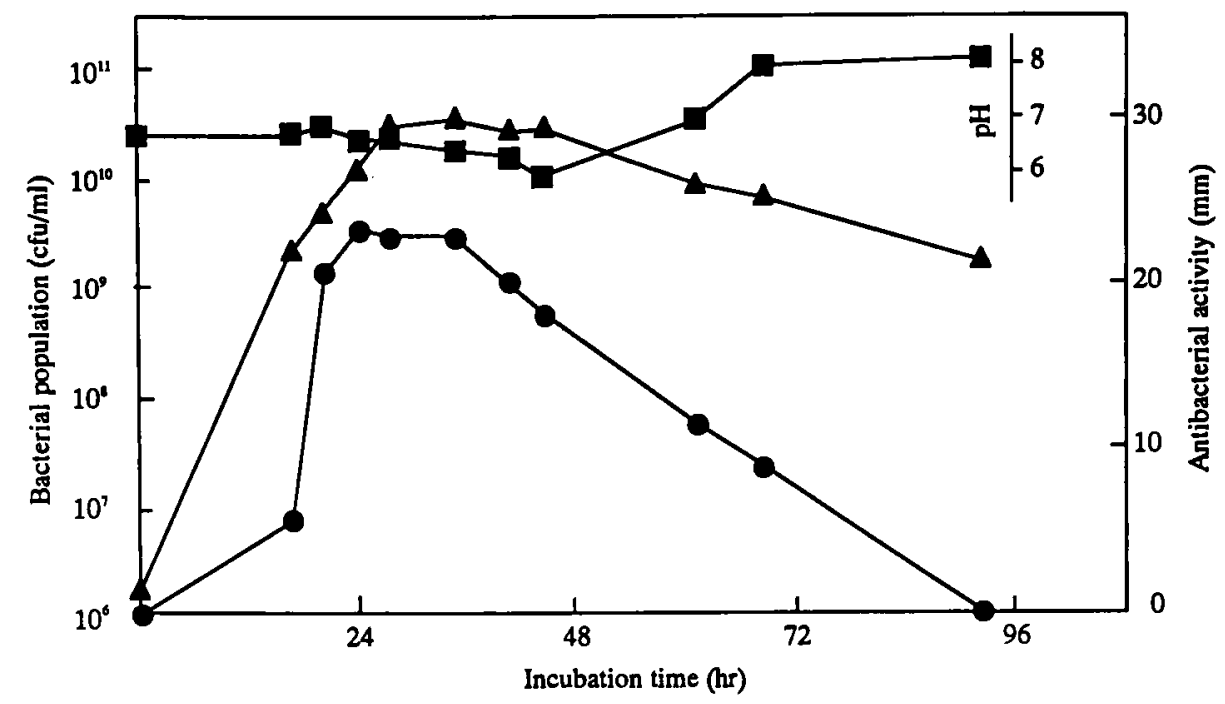

Fig. 1. Growth of Erwinia carotovora subsp. carotovora 493-1 under shake culture conditions in PS liquid medium, $\mathrm{pH}$ of its culture filtrate and activity against Pseudomonas solanacearum C319 over time. A. Bacterial population; $\mathbf{\square}, \mathrm{pH}$ of culture filtrate; $\bullet$, Anti-Pseudomonas solanacearum C319 activity as measured by the paper disk method.

Table 2. Anti-P. solanacearum activity' detected on various media by nine strains of Erwinia carotovora subsp. carotovora isolated in Thailand

\begin{tabular}{cccccccc}
\hline \hline \multirow{2}{*}{ Strain } & \multicolumn{7}{c}{ Medium $^{\text {b) }}$} \\
\cline { 2 - 6 } & PSA & PA & 523 & YPDA & KBA & MKA & MM \\
\hline $435-2$ & $++^{c}$ & +++ & +++ & ++ & ++ & - & - \\
$435-6$ & ++ & +++ & +++ & +++ & + & ++ & - \\
$473-1$ & ++ & ++ & +++ & + & - & - & - \\
$475-1$ & ++ & ++++++ & - & - & - & - \\
$489-4$ & ++ & +++ & - & - & - & - & - \\
$489-5$ & ++ & ++++++ & +++ & + & ++ & - \\
$493-1$ & ++ & ++++++++++ & ++ & ++ & - \\
$493-3$ & ++ & ++++++ & - & - & - & - \\
$493-5$ & ++ & ++++++ & + & + & - & - \\
\hline
\end{tabular}

a) Anti- $P$. solanacearum activity was estimated by the plate-chloroform method using strain C319 as an indicator.

b) Ingredients of each medium were shown in the text.

c) Activity index (diameter of inhibition zone): - , not detected ; + , less than $40 \mathrm{~mm} ;++, 40 \sim 60 \mathrm{~mm} ;+++$, greater than $60 \mathrm{~mm}$.

cultured at $30^{\circ} \mathrm{C}$ for $12-120 \mathrm{hr}$ under shake or still conditions. The bacterial population, antibacterial activity and $\mathrm{pH}$ in each culture fluid were sampled periodically during incubation. Sample activity was evaluated by the paper disk method ${ }^{12)}$ after the samples were sterilized by filtration through a Millipore filter $(0.2 \mu \mathrm{m})$. Under shake-culture conditions in PS liquid medium, all Thai strains produced antibacterial substance(s), similar to the case of strain 493-1 indicated in Fig. 1. None of the strains inhibited the indicator bacteria in still culture. Our results suggest that the Thai strains of $E$. carotovora subsp. carotovora produced several kinds of antibacterial substances depending upon the strain/medium combination. Furthermore, an unidentified substance(s) in the potato broth culture is favorable for the antibacterial substance(s) production. Ishimaru et al. ${ }^{\text {) }}$ showed that strain C9-1 of non-pathogenic Erwinia herbicola produced at least two antibiotics, herbicolin $\mathrm{O}$ and $\mathrm{I}$, which inhibited the growth of a wide variety of enterobacteria including Erwinia spp. Purification and characterization of the anti- $P$. solanacearum substance(s) produced by $E$. carotovora subsp. carotovora strain 493-1 are in progress. The utilization of these Erwinia spp. as a biological control agent after the deletion of pathogenicity is a subject for future study.

\section{Literature cited}

1. Furuya, N., Kushima, Y. and Matsuyama, N. (1992). Production of antibacterial substances by Pseudomonas glumae. J. Fac. Agric. Kyushu Univ. 37 : 149-158.

2. Furuya, N., Kushima,Y., Tsuchiya, K., Matsuyama, N. and Wakimoto, S. (1991). Protection of tomato seedlings by pre-treatment with Pseudomonas glumae from infection with Pseudomonas solanacearum and its mechanisms. Ann. Phytopathol. Soc. Jpn. $57:$ 363-370.

3. Furuya, N., Okamoto, T., Kori, Y., Matsuyama, N. and Wakimoto, S. (1991). Control of bacterial seedling rot of rice by avirulent strains of Pseudomonas glumae. Ann. Phytopathol. Soc. Jpn. 57 : 371-376.

4. Howell, C.R. and Stipanovic, R.D. (1979). Control of Rhizoctonia solani on cotton seedlings with Pseudomonas fluorescens and with an antibiotic produced by the bacterium. Phytopathology $69: 480-482$.

5. Howell, C.R. and Stipanovic, R.D. (1980). Suppression of Pythium ultimum induced damping-off of cotton seedlings by Pseudomonas fuorescens and its antibiotic, pyoluteorin. Phytopathology $70: 712-715$.

6. Isono, K., Nagatsu, J., Kawashima, Y. and Suzuki, S. (1965). Studies on polyoxin, antifungal antibiotics. Part I. Isolation and characterization of polyoxin A and B. Agric. Biol. Chem. 29 : 848-854. 
7. Ishimaru, C.A., Klos, E.J. and Brubaker, R.R. (1988). Multiple antibiotic production by Erwinia herbicola. Phytopathology 78 : 746-750.

8. Kado, C.I. and Heskett, M.G. (1970). Selective media for isolation of Agrobacterium, Corynebacterium, Erwinia, Pseudomonas and Xanthomonas. Phytopathology $60: 969-976$.

9. Kelman, A. (1954). The relationship of pathogenicity in Pseudomonas solanacearum to colony appearance on a tetrazolium medium. Phytopathology 44 : 963-965.

10. Kerr, A. (1980). Biological control of crown gall through production of agrocin 84 . Plant Dis. 64 : 25-30.

11. Kikutake, K., Matsuyama, N. and Wakimoto, S. (1991). Antagonistic activity of xanthomonads against phytopathogenic fungi and isolation of antifungal substance. Ann. Phytopathol. Soc. Jpn. 57 : 61-64.

12. Kunitake, S., Matsuyama, N. and Wakimoto, S. (1988). Production of proteinous anti-fungal substance(s) by Pseudomonas avenae Manns. Ann. Phytopathol. Soc. Jpn. $54: 640-642$.

13. Kunitake, S. and Matsuyama, N. (1989). Purification of anti-fungal substance produced by Pseudomonas avenae Manns. Ann. Phytopathol. Soc. Jpn. 55 : 366-368.

14. Matsuo, N., Matsuyama, N. and Wakimoto, S. (1981). Purification and some properties of a heat-stable antibacterial substance released from Xanthomonas campestris pv. citri Ku7101. Ann. Phytopathol. Soc. Jpn. $47: 472-479$

15. Matsuo, N., Matsuyama, N. and Wakimoto, S. (1981). Purification and some properties of the bacteriocin-like substance produced by Xanthomonas campestris pv. citri. Ann. Phytopathol. Soc. Jpn. $47:$ 480-487.

16. Matsuo, N., Matsuyama, N. and Wakimoto, S. (1981). Production of a specific bacteriocin by Xanthomonas campestris pv. citri. Ann. Phytopathol. Soc. Jpn. 47 : 571574.

17. Takeuchi, S., Hirayama, K., Ueda, K., Sakai, H. and Yonehara, H. (1958). Blasticidin S, a new antibiotic. J.
Antibiot. 11: 1-5.

18. Tsuyumu, S., Tsuchida, S., Makino, T. and Takikawa, Y. (1989). Antifungal activity in cell-free culture fluid of Pseudomonas solanacearum. Ann. Phytopathol. Soc. Jpn. $55:$ 9-15.

19. Umezawa, H., Okami, Y., Hashimoto, T., Suhara, Y., Hamada, M. and Takeuchi, T. (1965). A new antibiotic, Kasugamycin. J. Antibiot. 18: 101-106.

20. Wakimoto, S., Hirayae, K., Tsuchiya, K., Kushima, Y., Furuya, N. and Matsuyama, N. (1986). Production of antibiotics by plant pathogenic pseudomonads. Ann. Phytopathol. Soc. Jpn. 52 : 835-842.

\section{和 文 摘 要}

西岡正憲・古屋成人・中島信彦・松山宣明：Erwinia 属細菌代 謝産物の各種植物病原細菌に対する抗菌活性

日本および夕イ国各地で分離されたErwinia 属細菌 80 菌株 ๑ Agrobacterium tumefaciens, Clavibacter michiganensis subsp. michiganensis, Pseudomonas cepacia, P. solanacearum, $P$. syringae pv. syringae, Xanthomonas campestris pv. citri, $X$. oryzae pv. oryzae に対する抗菌物質産生性を調べた。その結果 $E$. carotovora subsp. carotovora, E. chrysanthemi pv. chrysanthemi, E. chrysanthemi pv. zeae, E. chrysanthemi （pathovar 未同定）を含む 39 菌株が 7 種指示菌の少なくとも 1 菌種に対して抗細菌活性を示す物質を産生した。，一方，P. cepacia およびX. campestris pv. citri に対し抗細菌活性を示す物 質産生性菌株は認められなかった。 夕イ国産のE. carotovora subsp. carotovora 4 菌株は平板培地上において $C$. michiganensis subsp. michiganensis, $X$. oryzae pv. oryzae t𠃌よび $P$. solanacearum に対して顕著な増殖阻止円を形成した。またタイ 国産の E. carotovora subsp. carotovora 493-1 株は, ジャガイモショ糖半合成液体培地あるいはジャガイモ煮汁液体培地で振と う培養した場合, $P$. solanacearum に対し抗菌活性を有する物質 を産生した。

(Received April 30, 1996 ; Accepted December 12, 1996) 